\title{
Effect of Pre-treatment on Quality Attributes of Pentaclethra macrophylla Benth Oil Expressed using an Oil Expeller: A Response Surface Approach
}

Clement Adesoji Ogunlade ( $\sim$ ogunlade.clement@adelekeuniversity.edu.ng )

Adeleke University https://orcid.org/0000-0002-8274-3937

Ademola Kabir Aremu

Department of Agricultural and Environmental Engineering, University of Ibadan

Rahman Akinoso

Department of Food Technology

\section{Research}

Keywords: Pentaclethra macrophylla kernels, pre-treatment variables, Oil quality, Models

Posted Date: July 8th, 2020

DOI: https://doi.org/10.21203/rs.3.rs-36805/v1

License: (c) (i) This work is licensed under a Creative Commons Attribution 4.0 International License.

Read Full License 


\title{
Effect of Pre-treatment on Quality Attributes of Pentaclethra macrophylla Benth Oil Expressed using an Oil Expeller: A Response Surface Approach
}

\author{
Ogunlade, C. A. ${ }^{1}$, Aremu, A. K. ${ }^{2}$ and Akinoso, R. \\ ${ }^{1}$ Department of Agricultural Engineering, \\ Adeleke University, Ede, Osun State, Nigeria \\ ${ }^{2}$ Department of Agricultural and Environmental Engineering, \\ University of Ibadan, Nigeria \\ ${ }^{3}$ Department of Food Technology, University of Ibadan, Nigeria
}

Corresponding author: Dr Ogunlade, Clement A.

Department of Agricultural Engineering, Adeleke University, Ede, Nigeria

ogunlade.clement@adelekeuniversity.edu.ng

Abstract: Investigations into some unexploited oleaginous seeds is imperative to supplement existing ones and boost supply of vegetable oil (VO). This work determined the impact of pre-treatment on some quality attributes of VO expressed from Pentaclethra macrophylla kernels using an oil expeller. Pre-treatment variables include Moisture Content (Mc), Roasting Temperature (RT), and Roasting Time (Rt) while quality parameters include $\mathrm{pH}$, Iron content (IC), Acid Value (Av), Peroxide Value (Pv) and Saponification value (Sv). Standard procedures were followed in determination of oil quality and values obtained were compared with acceptable levels for VO. Optimum condition (8\% db, $11.7 \mathrm{~min} \mathrm{Rt}$ and $59.3^{\circ} \mathrm{C} \mathrm{RT}$ ) gave $5.8 \mathrm{pH}, 0.044 \mathrm{mg} / \mathrm{kg} \mathrm{IC}, 2.3 \mathrm{mgKOH} / \mathrm{g} \mathrm{AV}$, and 7 $\mathrm{ml} / \mathrm{g}$ PV. The oil quality attributes conforms to acceptable levels for edible oils and was influenced by pretreatment. The models developed to predict the relationships between pre-treatment and quality attributes are valid $(\mathrm{p}<0.05)$.

\section{Keywords:}

Pentaclethra macrophylla kernels, pre-treatment variables, Oil quality, Models

\section{INTRODUCTION}

A very essential component of human diet is vegetable oil which is currently undergoing growth in its market due to incessant rise in the global population and its numerous applications by industries and individuals which has led to adulterations and illegalities both in preparation and supply in developing countries of the world (Ogu

nlade and Aremu, 2019). Several plants, nuts, seeds, and some underutilized specie have been explored howbeit, the already exploited oil bearing specie have not been able to meet the global request for vegetable oil for nutritional, industrial and pharmaceutical applications (Arinola and Ogunbusola, 2013) thus, investigations into some unexploited sources is imperative to supplement existing ones and boost supply. 
Pentaclethra macrophylla Benth is underutilized specie reportedly rich in many mineral salts, oil, energy, and protein with an ability of improving the human diets (Oyeleke et al., 2014). Pentaclethra macrophylla seed can be used for healing stomach disorders, wounds, iron deficiency, malnutrition, insomnia, reduce cancer risks, cure many tobacco related diseases and various other ailments (Bonnie, 2010). The kernels embedded in the seed has around $52 \%$ of vegetable oil which can further increased to around $60.1 \%$ or more with proper processing and handling (Enujiugha and Akanbi, 2005).

Oil can be extracted mechanically, traditionally, chemically or through supercritical fluid extraction; the method used directly affects the quality and volume of oil obtained (Aremu and Ogunlade, 2016a and b). Solvent extaction method has been explored for Pentaclethra macrophylla kernels (Onwuliri et al., 2004; Akindahunsi, 2004; Odoemelam, 2005; Enujiugha and Akanbi, 2005; Akubugwo et al., 2008; Sodiq, 2012) while mechanical method is currently been investigated (Ogunlade and Aremu, 2019; 2020) due to simplicity in design, construction and usage, versatility, high working capacity, easy adjustment of the working processes, minimal initial and operating costs. Parameters that affect the operational efficiency of the mechanical oil extraction method including processing, pre-treatment, crop conditions and operating parameters; but the rate of influence of each variable varies with nature of the biomaterial, and system adjustments (Akinoso, 2006) hence, it is essential to investigate impact of some parameters on oil yield and quantity. The effect of processing parameter on physical attributes of Pentaclethra macrophylla oil using oil expeller was reported (Ogunlade and Aremu, 2019) however; there is dearth of information on the degree of influence of pre-treatment on some quality attributes of oil obtained mechanically from Pentaclethra macrophylla kernels. This study therefore aimed at determining the impact of pretreatment (heat applications and moisture variations) on some quality attributes of Pentaclethra macrophylla oil using an oil expeller.

\section{METHODOLOGY}

Seed Procurement and Experimental Procedure: fresh seeds of Pentaclethra macrophylla were obtained from Ojoo market, Ibadan, Oyo State, Nigeria. They were dehulled, sorted and processed to varying levels of moisture obtained through addition of varying known water quantity using Equation 1 (Ogunlade and Aremu, 2019). The treated kernels were covered in closed polythene packs and stored under cold conditions for 2 days to promote uniform mix of moisture. Kernels were roasted in heating segment of the oil expeller (Fakayode and Ajav, 2016; Fakayode et al., 2016; Aremu and Ogunlade, 2016a and 2016b; Ogunlade and Aremu, 2019; 2020) at different time and temperatures intervals (Table 1), oil samples obtained were untouched for 4 days prior to further experimentations (Weiss, 2000).

$$
W=\frac{M(n-x)}{(100-n)}
$$

Where: $\mathrm{W}$ is added mass of water $(\mathrm{g}), M$ is weight of kernels $(\mathrm{g}), x$ is initial moisture level of kernels, $n$ is moisture level desired.

Quality Parameters Determination: the quality characteristics determined include $\mathrm{pH}$, iron content, acid, peroxide, and saponification value. They were determined in accordance with AOAC (2016) standard methods and compared with acceptable oil quality standards.

i. $\quad$ pH: $\mathrm{pH}$ meter $(\mathrm{pH}$ meter $(0.01 \mathrm{pH}, \pm 0.05 \mathrm{pH}$, United Kingdom) was used, the device was calibrated by first standardizing it with a buffer solution of $\mathrm{pH} 7$. Vegetable oil samples were measured out in a beaker and the electrode was properly cleansed with distilled water before dipping it in the oil, the result obtained were recorded.

ii. Iron content: Buck Model 205 Atomic Absorption Spectrophotometer (200/205/210/211 AA) calibrated with $100 \mathrm{mg} / \mathrm{l}$ of Iron standard solution was used to obtain level of iron contaminants in the oil (Kimboguila et al., 2010 and Oluremi et al., 2013). 
iii. Acid Value: this was determined in accordance with AOAC (2016) method. $25 \mathrm{ml}$ of diethyl ether, $25 \mathrm{ml}$ of alcohol (ethanol), $1 \mathrm{~g}$ of oil and $1 \mathrm{ml}$ of a solution of phenolphthalein (1\%) were mixed, shaken constantly and neutralised with $0.1 \mathrm{M}$ of sodium hydroxide until a pink colour was obtained and Acid Value (Av) was obtained using Equations (2 and 3) (Suleiman et al., 2013; Deepika et al., 2014):

$$
\begin{aligned}
& A v=\frac{\text { Titration }(\mathrm{ml}) \times 5.61}{\text { Weight of oil sample used }} \\
& A v=1.99 \times \mathrm{ffa}
\end{aligned}
$$

iv. Peroxide Value (Pv): this was also obtained in accordance with AOAC (2016); $1 \mathrm{~g}$ of KI (powdered) and $25 \mathrm{ml}$ of solvent mixture (2:1 volume/volume glacial: chloroform) was added to $1 \mathrm{~g}$ of the oil in a boiling tube, it was then moved to boiling water and left to boil for 30 seconds. The contents were poured to a flask with $30 \mathrm{ml}$ of water and titrated with $0.002 \mathrm{~N} \mathrm{Na}_{2} \mathrm{~S}_{2} \mathrm{O}_{3}$ with starch as indicator (Andarwulan et al., 2014; Nielsen, 2017; Asaad et al., 2020), Equation (4) was used for obtaining Pv.

$$
P v=\frac{10 x\left(V_{1}-V_{2}\right)}{m}
$$

Where: $\mathrm{V}_{1}$ is titre volume of $\mathrm{Na}_{2} \mathrm{~S}_{2} \mathrm{O}_{3} ; \mathrm{V}_{2}$ is blank volume of $\mathrm{Na}_{2} \mathrm{~S}_{2} \mathrm{O}_{3}$; $\mathrm{m}$ is the molarity

v. Saponification Value (Sv): titre metric method was used. $25 \mathrm{ml}$ of alcoholic Potassium hydroxide was added was added to $2 \mathrm{~g}$ of oil and placed in boiling water for 1 hour after which $1 \mathrm{ml}$ Phenolphthalein was introduced and titrated with $0.5 \mathrm{~N} \mathrm{HCl}$. Equation (5) was used for computing Sv:

$$
S v=56.1 \mathrm{~N} \frac{(X-Y)}{2}
$$

Where: $\mathrm{N}$ is $\mathrm{HCl}$ Normality, $\mathrm{X}$ is blank volume of $\mathrm{H}_{2} \mathrm{SO}_{4}(\mathrm{ml}), \mathrm{Y}$ is sample volume of $\mathrm{H}_{2} \mathrm{SO}_{4}(\mathrm{ml})$

Experimental Design: the levels of pre-treatment variables were obtained by preliminary investigations and literature, Tables 1 and 2 shows the level of variables and experimental runs using Response Surface Methodology (RSM) and version 10.0.1 of Design Expert.

Optimization and Modeling: models, optimum condition and general interactions between independent and respective responses were obtained using RSM. Seven (7) different models were tested to analyze the quality parameters as affected by changes in pretreatments. The appropriate model was obtained on the basis of lowest standard deviation values, highest coefficient of prediction, maximum Adjusted and predicted $\mathrm{R}^{2}$. Validation of models was obtained by fitting them into experimental data and comparing deviations. The criteria for optimization was based on FAO/WHO, CODEX-STAN-210-1999 standard for vegetable oil; the pre-treatment parameters were set at ranges; $\mathrm{pH}$ was set a target; iron content, acid value were minimized; peroxide and Saponification values were set at ranges. The general polynomial regression equation that predicted quality attributes of the oil is presented in Equation 6 (Khuri and Cornell, 2019; Ogunlade and Aremu, 2020):

$S r=\beta_{o}+\sum_{i=1}^{k} \beta_{i} X_{i}+\sum_{\mathrm{i}<} \sum_{j=3}^{k} \beta_{i j} X_{i} X_{j} X_{k}+\sum_{\mathrm{i}=1} \sum_{j=1}^{k} \delta_{i j} X_{i} X_{j} X_{k}+\varepsilon$

Where: $S r$ is the measured system response (quality characteristics), $\beta_{o}$ is the model intercept, $\sum_{i=1}^{k} \beta_{i} X_{i}$ represents influence of individual pretreatment variable, $\sum_{\mathrm{i}<} \sum_{j=2}^{k} \beta_{i j} X_{i} X_{j}$ considers relationship among variables, $\sum_{\mathrm{i}=1} \sum_{j=1}^{k} \delta_{i j} X_{i} X_{j}$ takes care of quadratic impact of parameters, $\boldsymbol{\varepsilon}$ is experimental random error, and $\mathrm{X}_{\mathrm{ijk}}$ considers matrix of the uncoded pretreatment parameter, $\boldsymbol{\beta}_{\mathrm{o}}, \boldsymbol{\beta}_{\mathrm{i}}, \boldsymbol{\beta}_{\mathrm{ij}}$ and $\boldsymbol{\delta}_{\mathrm{ij}}$ were determined through regression 
analysis, using the experimental empirical data.

\section{Model Validation:}

Optimum pre-treatment conditions were used to carry out experiments and the quality attributes were tested; actual values obtained were compared with calculated/predicted obtained from the models; Chi-square test was carried out to test the validity of the models for the empirical and predicted values to see if they are related (Subroto et al., 2015; Ogunlade and Aremu, 2020). Equation (7) was used to obtain the chi square in validating the models $\sum \frac{(E x-C l)^{2}}{(C l)}$

Where: Ex is the experimental value and $\mathrm{Cl}$ is the calculated/predicted value

\section{RESULTS AND DISCUSSION}

The influence of pre-treatment on some quality attributes of Pentaclethra macrophylla oil was investigated using oil expeller; it was observed that the degrees of influence of these variables are not equal. The sign and order of each parameter in the models indicate influence of each variable on the responses; +ve terms in the formulaes shows direct relationship between the variables (i.e. increase in such independent variable conduces increase in the corresponding dependent variable), while negative terms represent an inverse interaction between the variables (indicating a decrease in dependent variable when the value of that independent variable is increased). Optimum pre-treatment condition was obtained at $8 \% \mathrm{db}, 59.3^{\circ} \mathrm{C}$ and 11.71 minutes roasting temperature and time respectively. The results obtained is presented in Table 2, the coefficient of determination of all models tested and the chosen models including the optimum values and standard permissible values for each response is presented in Table 3.

\section{Effect of Pre-treamtent on the Quality Characteristics:}

i. $\quad$ pH: the $\mathrm{pH}$ ranged from 5.22 to 6.27 with an average value of $5.68 \pm 0.29$. this falls within FAO/WHO permissible values for vegetable oil (CODEX STAN, 1999). The relationship existing between pretreatment and $\mathrm{pH}$ was quadratic (Equation 8). Table 4 shows that all model terms were not significant ( $\mathrm{p}>0.05$ ), the result showed that Moisture Content (MC) has the highest influence on the $\mathrm{pH}$ also, $\mathrm{R}_{\mathrm{T}}, \mathrm{Mc}^{*}$ $\mathrm{Rt}, \mathrm{Mc} * \mathrm{Rt}$ and $\mathrm{R}_{\mathrm{T}}^{2}$ have positive influence on $\mathrm{pH}$, which implies that $\mathrm{pH}$ increases as these parameter and interactions increases while $\mathrm{pH}$ decreases as $\mathrm{MC}, \mathrm{Rt}, \mathrm{Rt} * \mathrm{R}_{\mathrm{T}}, \mathrm{Mc}^{2}, \mathrm{Rt}^{2}$ increases

$$
\begin{aligned}
& p H=8.88906-0.31875 M_{c}-0.10625 R_{t}+0.016812 R_{T}+0.0185 M_{c} * R_{t}+0.0008125 M_{c} * R_{T}- \\
& 0.00165 R_{t} * R_{T}-0.000625 M c^{2}-0.00095 R t^{2}+0.000190625 R_{T}^{2}
\end{aligned}
$$

Where: $\mathrm{MC}$ is the moisture content $(\% \mathrm{db}), \mathrm{Rt}$ is the Roasting time (min), RT is the Roasting temperature $\left({ }^{\circ} \mathrm{C}\right)$, while * represented interactions between the pre-treatment variables

ii. Iron Content: this ranged between 0.067-0.122 with an optimum value of 0.044 which conforms falls below the maximum acceptable value for vegetable oil (Table 3). Figure 1 shows that increase in pretreatments gave increase in the iron content but at a point, the iron content decreased with a further increase in moisture content, roasting time and temperature. Table 4 shows that models terms are not significant ( $\mathrm{p}>0.05)$. Quadratic relationship was observed between pretreatment and iron content (Equation 9) shows that increase in $\mathrm{Rt}, \mathrm{R}_{\mathrm{T}}$, and $\mathrm{Mc} * \mathrm{Rt}$ led to increase in iron content while an increase in Mc, $\mathrm{Mc} * \mathrm{R}_{\mathrm{T}}, \mathrm{Rt} * \mathrm{R}_{\mathrm{T}}$ and the square of all pretreatment variables gave a decrease in iron content $F e=-0.46593-0.07967 M_{c}+0.00218809 R_{t}+0.00159403 R_{T}+0.0008875 M_{c} * R_{t}-0.000084375 M_{c} *$ $R_{T}-0.00004125 R_{t} * R_{T}-0.00399148 M c^{2}-0.000328636 R t^{2}-0.0000117898 R_{T}^{2}$

iii. Acid Value (Av): this ranged between $2.67-4.06$ with an average and optimum value of 3.02 and 2.276 $\mathrm{mgKOH} / \mathrm{g}$ which falls within highest permissible tolerance level of $4 \mathrm{mgKOH} / \mathrm{g}$ (Table 3). Quadratic model predicting relationship between pretreatment and acid value is given in Equation (10). $A v=8.24077-1.12006 M_{c}-0.10889 R_{t}+0.02323 R_{T}+0.012375 M_{c} * R_{t}-0.00059375 M_{c} * R_{T}-$ $0.0010375 R_{t} * R_{T}+0.048153 M c^{2}+0.00165455 R t^{2}+0.000000965909 R_{T}^{2}$ 
Moisture content and heating applications had a rising impact on acid value which may be due to the oil hydrolysis process, water and lipase enzymes (Budijanto et al., 2008) which causes reduction in the amount of non-saturated fatty acids (Aremu et al., 2015), this again can be explained by the movement of water with oil from seed bed of the kernels during extraction processes which reacts with triglycerides to form glycerols (Akinhanmi and Akintokun, 2008)

iv. Peroxide Value (Pv): this ranged between 7.49-13.69 with an average and optimum value of 10.03 and $6.96 \mathrm{ml} / \mathrm{g}$ of oil which conforms with maximum permissible tolerance level of tolerance for virgin oil (Table 3). Equation 11 shows the quadratic model that represents relationship between pre treatment conditions and $\mathrm{Pv}$.

$P v=32.47685-2.716366 M_{c}-0.87402 R_{t}-0.11835 R_{T}-0.01775 M_{c} * R_{t}-0.005375 M_{c} * R_{T}-$ $0.005475 R_{t} * R_{T}+0.17443 M c^{2}+0.019659 R t^{2}+0.000597443 R_{T}^{2}$

The $\mathrm{Pv}$ increases as the moisture content increases while a linear relationship was observed between roasting temperature, time and $\mathrm{Pv}$ of the oil. This parameter how rancid oils are when measuring quality (Wannahari and Nordin, 2012); the low values obtained showed that the oil has low oxidative rancidity and antioxidants (Kyari, 2008).

v. Saponification Value (Sv): this ranged from $175.21-251.35$ with an average and optimum value of 203.4 and $202.979 \mathrm{mg} \mathrm{KOH} / \mathrm{g}$ (Table 3). The values obtained falls within acceptable levels for edible oils and are in tandem with soybean and groundnut oil (Aremu et al., 2015). The quadratic model suggested predicting the relationship between $S v$ and pre-treatment conditions is presented in Equation 12.

$S v=676.7574-28.82119 M_{c}-24.36636 H_{t}-2.86701 H_{T}+0.7445 M_{c} * H_{t}+0.056312 M_{c} * H_{T}-$

$0.011975 H_{t} * H_{T}+0.42372 M c^{2}+0.54395 H t^{2}+0.014456 H_{T}^{2}$

There was a slight rise in Sv heat application increases while the $\mathrm{Sv}$ decrease slightly as the moisture content increases, similar trend was reported by Ngassapa et al. (2012). This parameter determines level of oxidation and deterioration in storage; low Sv indicate oil suitability for soap making, cream and shampoos while high Sv indicate huge quantity of lower fatty acids.

\section{Validation of Models}

A meaningless difference exists between experimental and predicted values as presented in Table 5. The $X^{2}$ value is lower than the mark of 95\% level of confidence (Ogunlade and Aremu, 2020); this implies that a close relationship exists between model and experimental values. Hence, the models are valid at $95 \%$ level of confidence. The $\chi^{2}$ values of the quality attributes were: $0.0068,0.00037,0.00352,0.0156$ and $0.0017 \mathrm{for} \mathrm{pH}$, iron content, acid, peroxide and saponification values respectively; the small $\chi^{2}$ signifies that the observed values fits expected data well and means there is minimal deviation andhigh correlation.

\section{CONCLUSION}

The quality characteristics of mechanically expressed oil from Pentaclethra macrophylla was determined as affected by pre-treatment conditions like moisture content, roasting time and temperature. It was obtained that pretreatment has significant influence on the quality of the oil obtained from Pentaclethra macrophylla kernels including $\mathrm{pH}$, iron content, acid, peroxide, and Saponification values. Acceptable parameters for edibility were achieved by optimising the quality attributes within the range of pre-treatment variables using acceptable standards. Mathematical models developed to predict the quality parameters at various processing conditions showed an adequate representation and close agreement between predictions and experiments. The result otherwise obtained will be guide for food scientists, engineers, processors, agricultural engineers, and stakeholders involved production of vegetable oil from Pentaclethra macrophylla.

\section{ABBREVIATIONS}


Moisture Content $-\mathrm{Mc}$

Roasting Temperature - RT

Roasting Time - Rt

Iron content $-\mathrm{IC}$

Acid Value - Av

Peroxide Value - Pv

Saponification value $-\mathrm{Sv}$

DECLARATIONS

Ethics approval and consent to participate

We do solemnly declare that all authors have given their consent to the submission of this manuscript and they all participated in putting the manuscript together and conducting the research

\section{Consent for publication}

All authors hereby give their total consent for the publication of this article in Bioresources and Bioprocessing Journal

\section{Availability of data and materials}

The data materials for the study is available both in raw and analysed form.

\section{Competing interests}

Authors do solemnly declare that there are no conflict of interest for this study

\section{Funding}

Not Applicable

\section{Authors' contributions}

Ogunlade, C. A was involved in the conduct of the experiment, analysis and putting together of the manuscript. Aremu, A. K. and Akinoso, R. Were involved in the supervision of experiment, analysis of data and correction of manuscript

\section{Acknowledgements}

Authors are indebted to the Department of Agricultural and Environmental Engineering Department of the University of Ibadan for the access to their facilities and to Engr Dr Fakayode, Olugbenga Abiola for the design and construction of the oil expeller used for the research.

\section{REFERENCES}

Akindahunsi, A. A. 2004. Physiochemical studies of African oil bean (Penthaclethra Journal of Food, Agric and Environment.2: 14- 17

Akinhanmi, T. F. and Akintokun, P. O. 2008. Chemical Composition and Physico-Chemical Properties of Cashew Nut (Anacardium occidentale) Oil and Cashew Nut Shell Liquid. Journal of Agricultural, Food and Environmental Sciences, 2(1):5.

Akinoso, R. (2006). Effects of moisture content, roasting duration and temperature on yield and quality of palm kernel (Elaeis guineensis) and sesame (Sesamum indicum) oils (Ph.D. Thesis). Department of Agricultural Engineering, University of Ibadan, Nigeria.

Akubugwo, I. E., Chinyere, G. C. and Ugbogu, A. E. 2008. Comparative studies on oils from some common plant seeds in Nigeria. Pakistan Journal of Nutrition 7 (4): 570 - 573

Andarwulan, N., Gitapratiwi, D., Laillou, A., Fitriani, D., Hariyadi, P., Moench-Pfanner, R. and Martianto, D. 2014. Quality of vegetable oil prior to fortification is an important criteria to achieve a health impact. Nutrients, 6, 5051 - 5060 
AOAC (2016). Official methods of analysis. http://www.eoma.aoac.org/methods/info. asp?ID=16264, Washington, D. C.

Aremu, A. K. and Ogunlade, C. A. 2016a. Effect of operating parameters on mechanical oil expression from African oil bean seeds. Global Journal of Science Frontier Research: D, Agriculture and Veterinary, Vol. 16 Issue 1 Version 1.0: PP 19-26

Aremu, A. K. and Ogunlade, C. A. 2016b. Influence of Moisture Content and Seed Dimension on Mechanical Oil Expression from African Oil Bean (Pentaclethra macrophylla) seeds. Journal of Bio-systems Engineering. Vol. 41 (3).

Aremu, M. O., Ibrahim, H. Bamidele, T. O.. 2015. Physicochemical Characteristics of the Oils Extracted from Some Nigerian Plant Foods - A Review. Chemical Process Engineering Research, Vol. 32: pp 36 -52

Arinola, S. O. and E. M. Ogunbusola. 2013. Physicochemical characteristics and the effect of packaging materials on the storage stability of selected cucurbits oils. American Journal of Food Nutrition 1: 34-37.

Asaad Rehman Al-Hilphya, Sabah Malik Al-Shattya, Atheer Abdul Amir Al-Mturya, and Mohsen Gavahian (2020). Infrared-assisted oil extraction for valorization of carp viscera: Effects of process parameters, mathematical modeling, and process optimization. LWT - Food Science and Technology, 129: 109541. https:// doi.org/10.1016/j.lwt.2020.109541.

Bonnie, S. 2010. The nutritional value of African oil bean seeds. Retrieved Oct. 15, 2014, from www.livestrong.com/article/330704-the-nutrional-value of-oil-bean-seed/. $7: 31 \mathrm{pm}$

Budijanto, G.M.; Prasetyo, R.I. and Indraswati, N. (2008). Effects of Pre-Treatment Condition on the Yield and Quality of Neem Oil Obtained by Mechanical Pressing. ARPN Journal of Engineering and Applied Sciences. 3(5):45-49. ISSN 1819-6608

Codex Alimentarius. 1999. Codex standards for named vegetable oils. Vol. 8, Rome, pp. $12,22$. www.fao.org/3/y2774e/y2774e04.htm Accessed 25th May, 2020, 6:07 am

Deepika, D., Vegneshwaran, V. R., Julia, P., Sukhinder, K. C., Sheila, T., Heather, M. and Wade, M. 2014. Investigation on oil extraction methods and its influence on Omega-3 content from cultured salmon. Food Processing and Technology. Vol. 5 (12): 1 -13

Enujiugha, V. N. and Akanbi, C. T. 2005. Compositional changes in African oil Bean (Penthaclethra macrophylla) seeds during thermal processing. Pakistan Journal of Nutrition ISSN 1680-5194. 4(1): 27-31

Fakayode, O. A. and Ajav, E. A. (2016). Process optimization of mechanical oil expression from moringa (Moringa oleifera) seeds. Industrial Crops and Products, 90, 142-151.

Fakayode, O. A., Ajav, E. A. and Rahman Akinoso. Effects of processing factors on the quality of mechanically expressed Moringa (Moringa oleifera) oil: A response surface approach J. Food Process Eng. 2016; 1-12 wileyonlinelibrary.com/journal/jfpe

Kimbonguila, A., Nzikou, J. M., Matos, L., Loumouamou, B., Ndangui, C. B., Pambou-Tobi, N. P. G., Abena, A. A., Silou, T., Scher, J. and Desobry, S. 2010. Proximate Composition and Physicochemical Properties on the Seeds and Oil of Annona muricata grown In Congo-Brazzaville. Research Journal of Environmental and Earth Sciences, 2 (1): 13 - 18.

Khuri, A. I., \& Cornell, J. A. (2019). Response surfaces: Designs and analyses (2nd ed.). CRC Presshttps://www.bookdepository.com/Response-Surfaces-Designs-Analyses-AndreIKhuri/9780367401252

Kyari, M. Z. 2008. Extraction and characterization of seed oils. International Agrophysics 22: 139-1142.

Ngassapa, F. N. and Othman, O. C. 2001. Physicochemical characteristics of some locally manufactured edible vegetable oils marketed in Dar Es Salaam. Tanzania Journal of Science 27.1: 49-58.

Nielsen, S. S. (Ed.). (2017). Food analysis. Springer International Publishinghttps://doi. org/10.1007/978-3-31945776-5

Odoemelam, S. A. 2005. Proximate composition selected physicochemical properties of the seeds of African oil bean (Pentaclethra macrophylla). Pakistan Journal of Nutrition, 4, 382 - 383 
Ogunlade, C. A. and Aremu, A. K. (2019). Influence of Processing Conditions on Yield and Quality of Mechanically Expressed African Oil Bean (Pentaclethra macrophylla Benth) Kernels: A Response Surface Approach. Journal of Food Process Engineering, John Wiley. 42 (2): 1-9. https://doi.org/10.1111/jfpe.12967 and https://onlinelibrary.wiley.com/doi/pdf/10.1111/jfpe.12967

Ogunlade, C. A. and Aremu, A. K. (2020). Modeling and optimisation of oil recovery and throughput capacity in mechanically expressing oil from African oil bean (Pentaclethra macrophylla Benth) kernels. Journal of Food Science and Technology. J Food Sci Technol (2020).https://doi.org/10.1007/s13197-020-04435-0. http://link.springer.com/article/10.1007/s13197-020-04435-0

Oluremi, O. I., Ajayi, O. S. and Adekunle, A. S. 2013. Fatty acids, metal composition and physico-chemical parameters of Igbemo Ekiti Rice Bran Oil. Journal of Environmnetal Chemistry and Ecotoxicology, Vol. 5(3): $39-46$

Onwuliri, V.A., I. Attah and J.O. Nwankwo, 2004. Anti-nutritional factors, essential and non-essential fatty acids composition of Ugba (Pentaclethra macrophylla) seeds at different stages of processing and fermentation. J. Biological Sci., 4: 671-675.

Oyeleke, G. O., Olagunju, E. O. and Ojo, A. 2012. Functional physicochemical properties of watermelon (Citrullus lanatus) seed seed-oil. Journal of Applied Chemistry, 2(2), 29 - 31.

Sodiq, O. M. 2012. Effect of microwave heating as a pretreatment on quality and quantity of African oil bean seed. Unpublished M Sc Project, Dept. of Food technology, University of Ibadan

Subroto, E., Robert, M., Hero. J. H. and Antonius, A. B. 2014. Optimisation of mechanical oil extraction from Jatropha curcas L.kernel using response surface method. Journal of Industrial Crops 63: 294-302.

Sulieman, A. M. E., Mashear, B., Mohammed, Ali O. Ali. 2013. Physicochemical and Sensory Properties of Traditionally and Laboratory Made Ghee (Samin) of the Sudan. International Journal of Food Science and Nutrition Engineering, 3 (1): 7 - 11

Wannahari. R and Nordin. M.F.N. 2012. Reduction of Peroxide Value in Used Palm Cooking Oil Using Bagasse Adsorbent. American International Journal of Contemporary Research, 2 (1): 185 - 191 

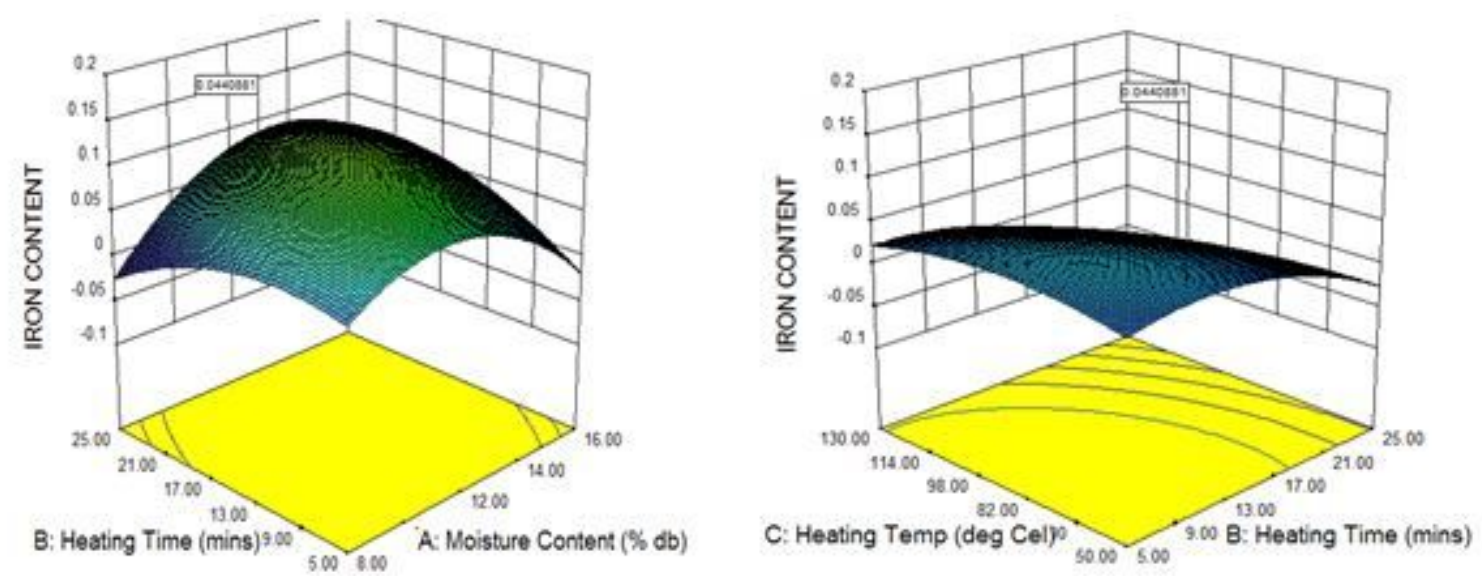

\section{Figure 1}

Response of iron content to changes in Moisture content, Roasting Temperature and time

\section{Supplementary Files}

This is a list of supplementary files associated with this preprint. Click to download.

- GRAPHICALABSTRACT.JPG 